\title{
STRUKTUR NARATIF LEGENDA CANDI PARI DAN CANDI SUMUR DI KECAMATAN PORONG KABUPATEN SIDOARJO
}

\author{
Mifta Khuljannah $^{1}$, Sucipto ${ }^{2}$, Boedi Martono ${ }^{3}$ \\ ${ }_{1,2,3}$ FKIP Universitas Dr. Soetomo \\ Jalan Semolowaru 84 Surabaya \\ Email: nenkahmad4@gmail.com ${ }^{1}$, kangsucipto@yahoo.co.id ${ }^{2}$, \\ boedimartono14@gmail.com ${ }^{3}$
}

\begin{abstract}
Abstrak
Salah satu budaya yang masih melekat pada masyarakat adalah sastra lisan. Sastra lisan sudah ada sebelum masyarakat mengenal sastra tulis, tetapi keberadaannya sulit untuk dilestarikan karena bergantung pada penutur tersebut. Berkaitan dengan itu, peneliti tertarik dan berkeinginan untuk menggali tentang struktur naratif legenda Candi Pari dan Candi Sumur di Kecamatan Porong Kabupaten Sidoarjo.Teori yang digunakan dalam penelitian ini adalah teori analisis naratif ala Maranda dan sastra perbandingan milik Kasim. Metode yang digunakan adalah deskriptif kualitatif karena data yang dianalisis berupa kata-kata atau kalimat. Sumber data berasal dari wawancara mendalam dengan beberapa informan. Teknik pengumpulan data yang dilakukan peneliti yaitu obsrvasi, wawancara, rekaman, pencatatan, dokumentasi, teknik transkip, dan teknik transliterasi. Untuk memperoleh data yang valid, peneliti menggunakan triangulasi sumber dengan membandingkan informasi yang diperoleh dari beberapa informan yang berbeda. Hasil penelitian ini menunjukkan bahwa adanya keterkaitan struktur naratif term dan fungsi dalam legenda Candi Pari dan Candi Sumur. Karakteristik yang paling menonjol antara dua candi itu adalah Candi Pari selalu identik dengan tempat ibadah bagi umat beragama Hindu, sedangkan Candi Sumur digunakan sebagai tempat untuk mengambil air guna menyucikan diri sebelum beribadah di Candi Pari.
\end{abstract}

Kata kunci: legenda, struktur naratif, sastra bandingan, candi

\section{NARRATIVE STRUCTURE OF THE PARI AND SUMUR TEMPLES IN THE PORONG DISTRICT OF SIDOARJO REGENCY}

\begin{abstract}
One culture that is still inherent in society is oral literature. Oral literature existed before the public recognized written literature, but its existence is difficult to preserve because it depends on the speaker. In this connection, the researcher was interested and wanted to explore the narrative structure of the Pari and Sumur Temples in Porong District, Sidoarjo Regency. The theory used in this research was Maranda's narrative analysis theory and Kasim's comparative literature. The method used is descriptive qualitative because the data analyzed in the form of words or sentences. Data sources came from in-depth interviews
\end{abstract}


with several informants. Data collection techniques used by researchers are observation, interviews, recording, recording, documentation, transcript techniques, and transliteration techniques. To obtain valid data, researchers used source triangulation by comparing information obtained from several different informants. The results of this study indicate that there is a linkage between the term narrative structure and function in the legend of Pari Temple and Sumur Temple. The most prominent characteristic between the two temples is that the Pari Temple is always synonymous with places of worship for Hindus, while the Sumur Temple is used as a place to take water to purify oneself before worshiping at Pari Temple.

Keywords: legend, narrative structure, comparative literature, temple

\section{A. Pendahuluan}

Legenda (legend) ialah prosa rakyat yang memiliki kemiripan ciri dengan mite, yaitu dianggap benar adanya terjadi, tetapi tidak dianggap suci, manusia sebagai tokoh dalam legenda, meskipun ada kalanya memiliki sifat-sifat luar biasa yang dibantu oleh makhluk astral (Yulianto, 2016:79). Tempat terjadinya adalah di dunia seperti yang kita kenal saat ini, karena terjadinya belum terlalu lampau. Legenda dapat bersifat suci dan manusia sebagai tokoh utamanya (Setyorini \& Riskiana, 2018:213). Legenda juga berkembang sebagai sastra lisan sebagai wujud kebudayaan masyarakat tertentu yang disebarkan dan diturun temurunkan secara lisan dari mulut ke mulut (Putri \& Nugraha, 2017:203). Legenda memiliki ciri khas dibandingkan dengan sastra lisan lainnya yaitu berhubungan dengan sejarah rakyat sebagai bagian dari peristiwa-peristiwa sejarah (Danandjaja, 2007; Murniati, 2019:8). Dalam legenga juga ada unsur imajinasi dan mitos sehingga masuk dalam karya fiksi (Barthes, 2006).

Di dalam sastra lisan penggunaan pendekatan struktural sudah banyak dilakukan, misalnya pendekatan formula-formulaik Albert lord dan struktur mitos Levi-Strauss. Selain itu, muncul juga teori-teori struktur karya sastra misalnya, structural model in foklore and transformational essays yang ditulis oleh Elly Kongas Maranda dan Pierre Maranda, the morfology of folktaleyang ditulis oleh Vladimir Propp, dan penelitian-penelitian lain yang ditulis oleh para ahli seperti Ben Amos, Alan Dundes, Heda Jason, dan sebagainya (Hutomo, 1991:23-28).

Tulisan ini bertujuan untuk membahas struktur naratif yang dipelopori oleh Elli Kongas Maranda dan Pierre Maranda yang memiliki dua indikator yakni terem 
dan fungsi terhadap legenda Candi Pari dan Candi Sumur yang terletak di daerah Porong, Kabupaten Sidoarjo. Sebagai bentuk sebuah peninggalan sejarah pada masa silam. Oleh karena keunikan dari Legenda Candi Pari dan Candi Sumur yang ceritanya memiliki suatu keterkaitan satu sama lain ini membuat peneliti ingin menelitinya dengan menggunakan teori struktural. Selain itu, peneliti juga akan menganalisis lebih dalam lagi menggunakan sastra bandingan milik Kasim yang meliputi beberapa indikator yakni tema, alur, latar, dan hubungan karya satra dengan kepercayaan.

Dengan penggunaan dua teori tersebut, peneliti menggunakan 3 rumusan masalah, yang pertama adalah Bagaimana keterkaitan unsur-unsur terem pada Legenda Candi Pari dan Candi Sumur? Yang kedua yaitu Bagaimana keterkaitan unsur-unsur fungsi dalam Legenda Candi Pari dan Candi Sumur? Kemudian, yang ketiga, Bagaimana keterkaitan unsur-unur struktur narati pada Legenda Candi Pari dan Candi Sumur di Kecamatan Porong Kabupaten Sidoarjo?

Dalam penelitian Legenda Candi Pari dan Candi Sumur, peneliti membahas tentang struktur yang ada pada dua candi tersebut. Belum ada pembahasan secara mendetail mengenai strutktur yang dimiliki dua candi, yang ada hanyalah pembahasan mengenai akulturasi yang dimliki seperti penelitian yang dilakukan oleh Sari (2017) yang berjudul Anasir-Anasir Akulturasi Pada Candi Pari. Kemudian, penelitian oleh Astuti (2016) yang berjudul Legendha Candhi Pari Lan Candhi Sumur Ing Desa Candipari Kecamatan Porong Kabupaten Sidoarjo.

Dari beberapa penelitian relevan di atas, menunjukkan bahwa struktur legenda naratif Candi Pari dan Candi Sumur di Kecamatan Porong Kabupaten Sidoarjo belum diteliti. Hasil penelitian ini diharapkan bermanfaat dalam melestarikan salah satu warisan budaya Indonesia dan dapat dijadikan sebagai bahan ajar prosa fiksi.

\section{B. Metode Penelitian}

Metode yang digunakan dalam penelitian ini adalah metode deskriptif kualitatif. Penelitian ini menggunakan jenis deskriptif karena mendeskripsikan objek berupa kejadian yang dijadikan sebagai kajiannya. Metode kualitatif dengan 
pendekatan deskriptif ini mengutamakan kualitas data. Berdasarkan hal tersebut, dapat dikatakan bahwa hasil dari penelitian ini adalah kata tertulis yang berasal dari informan sebagai pelaku budaya. Objek penelitian ini pun bukan gejala sosial yang ada di masyarakat, melainkan makna yang terkandung di balik tindakan gejala sosial tersebut. Data dalam penelitian ini berupa kata-kata, kalimat dalam paragraf Legenda Candi Pari dan Candi Sumur, dan data yang diperoleh dari hasil wawancara dengan beberapa informan Candi Pari dan Candi Sumur. Sumber data dalam penelitian ini adalah hasil wawancara dari juru pelihara Candi Pari dan Candi Sumur di Kecamatan Porong, Kabupaten Sidoarjo. Untuk memilih informan atau juru pelihara, peneliti memeiliki beberapa kriteria yang akan digunakan a) enkulturasi penuh adalah informan tersebut mengenal dan tinggal dalam lingkungan budayanya; b) keterlibatan langsung adalah informan tersebut masih hidup dan berperan dalam lingkungan budayanya; c) suasana asing bagi peneliti adalah latar belakang kebudayaan informan masih asing bagi peneliti; d) waktu yang cukup adalah informan tidak sibuk dan berantusias terhadap fokus penelitian; dan e) nonanalitis adalah informan dapat merespons fokus dengan baik dan memberi informasi yang apa adanya (Spradley dalam Sudikan, 2001:168).

Instrumen sangatlah diperlukan dalam sebuah penelitian untuk mendapatkan data yang valid. Dalam penelitian dengan jenis kualitatif, peneliti berperan sebagai pengumpul data utama dan sebagai instrumen aktif dalam upaya mengumpulkan data-data di lapangan. Seorang peneliti berperan sebagai perencana, pelaksana pengumpulan data, analisis, penafsiran data, dan pada akhirnya peneliti menjadi pelapor hasil penelitiannya (Moleong, 2016:168). Adapun beberapa instrumen pendukung dalam melakukan proses penelitian yaitu berupa buku catatan kecil, alat rekam, kamera, pertanyan terstrukur yang sudah mendapat validitas dari beberapa ahli sastra. Teknik pengumpulan dan keabsahan data pada tahap ini dilakukan sebuah usaha untuk membuat data tersebut bisa muncul. Beberapa teknik yang dilakukan yaitu: observasi, wawancara, perekaman, pencatatan, dokumentasi, transkripsi, dan terjemah data.

Silampari Bisa: Jurnal Penelitian Pendidikan Bahasa Indonesia, Daerah, dan Asing Vol. 3, No. 1, 2020 
Teknik analisis data merupakan bagian yang tidak dapat terpisahkan dari teknik pengumpulan data, utamanya dalam penelitian sastra lisan data dan informasi yang terkumpul selanjutnya ditafsirkan ceritanya dibantu dengan teori yang digunakan yakni struktur naratif. Berikut beberapa teknik analisis data yang digunakan peneliti: a) data rekaman ditranskripsikan, dari bentuk rekaman ke dalam bentuk tulisan; b) setelah ditranskripsikan, data kemudian ditransliterasi; c) membaca kembali cerita sampai memenuhi seluruh isi cerita untuk menangkap gambaran tentang masalah yang ingin diteliti; d) memisahkan transkrip data berupa cerita dan data yang berhubungan dengan desa Candi Pari dan Candi Sumur; e) identifikasi dan pengelompokan data yang sesuai dengan arah kajian penelitian; f) analisis terhadap legenda Candi Pari dan Candi Sumur, dengan menggunakan teori struktur naratif dalam cerita tersebut; g) analisis terhadap struktur naratif Legenda Candi Pari dan Candi Sumur menggunakan teori sastra bandingan; h) menguji keabsahan data dengn menggunakan triangulasi sumber; dan i) menyimpulkan hasil analisa berdasarkan pendeskripsian yang dilakukan sebelumnya.

\section{Hasil Penelitian dan Pembahasan}

\section{Hasil Penelitian}

Dari hasil analisis data struktur naratif Candi Pari dan Candi Sumur di Kecamatan Porong, Kabupaten Sidoarjo, diperoleh informasi sebagai berikut.

Tabel 1. Kode Terem Candi Pari dan Candi Sumur di Kecamatan Porong, Kabupaten Sidoarjo

\begin{tabular}{clcl}
\hline & \multicolumn{1}{c}{ Terem Candi Pari } & \multicolumn{2}{c}{ Terem Candi Sumur } \\
\hline A & Candi Pari & a & Kerajaan Majapahit \\
\hline a1 & Jaka Pandelegen & a1 & Prabu Brawijaya \\
\hline a2 & Candi Sumur & a2 & Kedung Suko/Ras \\
\hline a3 & Nyai Roro Walang Angin & a3 & Jaka Walang Tinunu \\
\hline a4 & Kerajaan Majapahit & a4 & Nyai Roro Walang Sangit \\
\hline B & Raja Hayam Wuruk & a5 & Jaka Pnadelegen \\
\hline b1 & Desa Kedung Ras & b & Nyai Roro Walang Angin \\
\hline b2 & Prajurit & b1 & Lumbung Padi \\
\hline
\end{tabular}

Silampari Bisa: Jurnal Penelitian Pendidikan Bahasa Indonesia, Daerah, dan Asing Vol. 3, No. 1, 2020 


\begin{tabular}{clcl}
\hline b3 & Jaka Walang Tinunu & b2 & Orang desa \\
\hline b4 & Lereng Penanggungan & b3 & Patih dan Prajurit \\
\hline b5 & Janda Injingan & c & Candi Pari \\
\hline C & Lumbung padi & c1 & Candi Sumur \\
\hline c1 & Sumur & & \\
\hline
\end{tabular}

Ada 13 terem yang terdiri dari $a(4): b(5): c(1) \quad$ Ada 12 terem yang terdiri $a(5): b(3): c(1)$

\section{Pembahasan}

Struktur naratif legenda Candi Pari dan Candi Sumur saling memiliki keterkaitan term dan fungsi. Karakteristik yang paling menonjol antara dua candi itu adalah Candi Pari selalu identik dengan tempat ibadah/pemujaan bagi umat beragama Hindu, sedangkan Candi Sumur digunakan sebagai tempat untuk mengambil air guna menyucikan diri sebelum beribadah di Candi Pari. Hal ini menunjukkan bahwa memang Candi berfungsi sebagai tempat beribadah dan juga tempat mengambil air guna menyucikan diri sebelum beribadah bagi umat Hindu (Sari, 2017; Astuti, 2016). Kemudian, legenda Candi Pari dan Candi Sumur memiliki persamaan tema tentang kepahlawanan, dalam Legenda Candi Pari mengisahkan tentang jasa kebaikan Jaka Pandelegen dan Nyai Roro Walang Angin, atas kebaikannya kepada kerajaan Majapahit yang dipimpin oleh Raja Hayam Wuruk, dalam Legenda Candi Sumur mengisahkan tentang jasa kebaikan Jaka Pandelegen dan Nyai Roro Walang Angin.

Dalam legenda Candi Pari terdapat 13 terem a(4): b(5): c (1), dari struktur tersebut jika dilihat dari segi tokoh maka akan tampak seperti berikut :

$$
N:\left(a_{1}\right):\left(a_{3}\right)::(b):\left(b_{2}\right)::\left(b_{3}\right):\left(b_{5}\right)::
$$

Deskripsi: Jaka Pandelegen, Nyai Roro Walang Angin. Raja Hayam Wuruk, prajurit. Jaka Walang Tinunu, Janda Injingan.

Dalam legenda Candi Sumur terdapat ada 12 terem yang terdiri $a(5): b(3): c(1)$, dari struktur tersebut jika dilihat dari segi tokoh maka akan tampak seperti berikut:

$$
N:\left(a_{1}\right)::\left(a_{3}\right):\left(a_{4}\right)::\left(a_{5}\right):(b)::\left(b_{2}\right)::\left(b_{3}\right)::
$$


Deskripsi : Prabu Brawijaya. Jaka Walang Tinunu, Nyai Roro Walang Sangit. Jaka Pandelegen, Nyai Roro Walang Angin. Orang desa, patih dan prajurit.

Tabel 2. Fungsi Candi Pari dan Candi Sumur

\begin{tabular}{|c|c|c|c|}
\hline \multicolumn{2}{|r|}{ Fungsi Candi Pari } & \multicolumn{2}{|r|}{ Fungsi Candi Sumur } \\
\hline $\mathrm{X}$ & moksa & $\mathrm{x}$ & terkenal \\
\hline$x 1$ & mencari bantuan & $x 1$ & memanen \\
\hline$x 2$ & melimpah & $x 2$ & keanehan \\
\hline$x 3$ & menyuruh & $x 3$ & paceklik/gagal panen \\
\hline $\mathrm{x} 4$ & diboyongkan & $x 4$ & mendengar \\
\hline $\mathrm{x} 5$ & bertanya & $x 5$ & minta sumbangan \\
\hline$x 6$ & menikahi & $x 6$ & menyumbangkan \\
\hline $\mathrm{Y}$ & tidak menyampaikan & $\mathrm{y}$ & dipersembahkan \\
\hline $\mathrm{y} 1$ & rahasia & $\mathrm{y} 1$ & tetap tinggal \\
\hline $\mathrm{y} 2$ & diangkat derajatnya & $\mathrm{y} 2$ & diboyong \\
\hline y3 & pemberian & y3 & memaksa \\
\hline y4 & bukan miliknya & $\mathrm{y} 4$ & menangkap \\
\hline y5 & tidak mau meninggalkan & y5 & diberi suatu kesalahan \\
\hline Z & menolak & y6 & bersembunyi \\
\hline$z 1$ & menangkap & $z$ & moksa/hilang tanpa jejak \\
\hline $\mathrm{z2}$ & meminta izin & $\mathrm{z1}$ & mengambil air \\
\hline$z 3$ & hilang & $z 2$ & sakti \\
\hline$z 4$ & membangun & & \\
\hline & $18(x 6+y 5+z 4)$ & & $17(y 6+y 6+z 2)$ \\
\hline
\end{tabular}

Dalam Legenda Candi Pari terdapat terdapat 18 fungsi ( x6 + y5 $+z 4$ ). komposisi kebaikan dan keburukan.

$$
N:\left(y_{3}\right):\left(a_{1}\right):\left(b_{3}\right):(b)_{x 4}::(b)_{z 4}:\left(a_{1}\right):\left(a_{3}\right)::(b)_{y 1}: x_{6}\left(b_{5}\right)::
$$

Deskripsi :

1) Atas pemberian padi oleh Jaka Pandelegen dan Jaka Walang Tinunu, Raja Hayam Wuruk akan memboyong ke kerajaan.

2) Raja Hayam Wuruk meminta para prajurit untuk membangunkan candi untuk mengenang Jaka Pandelegen dan Dewi Roro Walang Angin.

3) Raja Hayam Wuruk Merahasiakan bahwa dia pernah menikahi Janda Injingan.

Dapat dilihat bahwa fungsi kebaikan dalam Legenda Candi Pari lebih besar daripada fungsi keburukan. Walupun sekarang candi sudah banyak berubah fungsi salah satunya menjadi tempat rekreasi dunia karena berkedudukan sebagai warisan dunia dan karya besar nenek moyang bangsa Indonesia 
(Wahyuningsih, 2016:48). Kemudian, dalam Legenda Candi Sumur terdapat terdapat 17 fungsi yang terdiri dari ( y6 + y6 + z2 ) komposisi kebaikan dan keburukan.

$$
N:\left(a_{3}\right):\left(a_{5}\right)_{x 6}: \times\left(a_{1}\right)::\left(a_{1}\right):\left(b_{3}\right)_{y 4}: y_{3}\left(a_{5}\right):(b)::\left(a_{1}\right):\left(b_{3}\right)_{y 5}:\left(a_{5}\right):(b)::
$$

Deskripsi :

1) Jaka Walang Tinunu dan Jaka Pandelgen bersedia menyumbangkan sebagian padinya untuk dipersembahkan kepada Prabu Brawijaya.

2) Prabu Brawijaya mengutus patih dan prajuritnya untuk menangkap dengan paksa Jaka Pandelegen dan Nyai Roro Walang Angin.

3) Prabu Brawijaya akan memberikan suatu kesalahan kepada Jaka Pandelegen dan istrinya Nyai Roro Walang Angin agar mau dibawa ke kerajaan.

Dapat dilihat bahwa fungsi keburukan dalam Legenda Candi Sumur lebih besar daripada fungsi kebaikan.

Tema: kepahlawanan untuk mengenang jasa Jaka Pandelegen dan istrinya, Raja Hayam Wuruk membangunkan Candi untuk sepasang suami istri tersebut.

$$
N:\left(a_{1}\right):\left(a_{3}\right)::(b)_{z 4}:: \underline{(C P)}
$$

Kepahlawanan untuk mengenang jasa Jaka Pandelegen dan istrinya, Prabu Brawijaya membangunkan Candi untuk sepasang suami istri tersebut.

$$
N:\left(a_{5}\right):(b)_{z 2}::\left(a_{1}\right):: \underline{(C S)}
$$

Alur cerita berbentuk alur mundur karena proses jalannya cerita yang tidat urut, dapat dilihat dari pengawalan cerita yang langsung menjelaskan inti cerita. Walupun alur mundur memiliki rangkaian cerita mulai dari pengenalan, konflik, klimaks, peleraian, dan penyelesaian (Noermanzah, 2017:33). Berikut pola alurnya.

$$
N:(a)_{x}:\left(a_{1}\right):\left(a_{2}\right)_{x}:\left(a_{3}\right):: \underline{(C P)}
$$

Alur maju karena proses jalannya cerita berjalan dengan urut, dapat dilihat dari tahapan perkenalan cerita, kemudian sampai ke tahapan penyelesaian secara urut.

$$
N:(a):\left(a_{1}\right):\left(a_{2}\right)::\left(a_{5}\right):(b):: \underline{(C S)}
$$


Latar waktu yaitu pada zaman Kerajaan Majapahit (dipimpin oleh Raja Hayam Wuruk), masa lampau.

$$
N:\left(a_{4}\right):(b)::
$$

Tempat yaitu kerajaan, Kedung Ras, Lereng Penanggungan, dan Lumbung Padi, Sumur.

$$
N:\left(a_{4}\right):\left(b_{1}\right):\left(b_{4}\right):(c):\left(c_{1}\right)::
$$

Susasana dalam bentuk mengharukan dengan pola sebagai berikut.

$$
\mathrm{N}:(\mathrm{b})_{\mathrm{y}}:\left(\mathrm{b}_{3}\right)::(\mathrm{b})_{\mathrm{y} 1}:\left(\mathrm{b}_{3}\right):\left(\mathrm{b}_{5}\right):: \underline{(\mathrm{CP})}
$$

Waktu pada zaman Kerajaan Majapahit (dipimpin oleh Prabu Brawijaya), masa lampau.

$$
N:(a):\left(a_{1}\right)::
$$

Tempat yaitu kerajaan, Desa Suko, sawah, Pamotan, lumbung padi, dan sumur.

$$
N:(a):\left(a_{2}\right):\left(b_{4}\right):\left(b_{1}\right):\left(c_{1}\right)::
$$

Suasana dalam bentuk menegangkan dengan pola sebagai berikut.

$$
\mathrm{N}:\left(\mathrm{a}_{1}\right)_{\text {y } 2}:\left(\mathrm{a}_{5}\right):(\mathrm{b})::\left(\mathrm{a}_{1}\right):\left(\mathrm{b}_{3}\right)_{\text {y5 } \mathrm{y} 2}:(\mathrm{a}) \underline{\mathrm{CS}}
$$

Kepercayaan untuk dijadikan tempat sembahyang/pemujaan Dewa bagi umat Hindu (CP). Untuk pengambilan air suci, sebelum menuju ke tempat sembahyang (Candi Pari) (CS). Dengan demikian, terdapat beberapa persamaan dan perbedaan antara legenda Candi Pari dan Candi Sumur, sebagai berikut.

a. Legenda Candi Pari dan Candi Sumur memiliki persamaan tema tentang kepahlawanan, dalam Legenda Candi Pari mengisahkan tentang jasa kebaikan Jaka Pandelegen dan Nyai Roro Walang Angin, atas kebaikannya kepada kerajaan Majapahit yang dipimpin oleh Raja Hayam Wuruk, dalam Legenda Candi Sumur mengisahkan tentang jasa kebaikan Jaka Pandelegen dan Nyai Roro Walang Angin, atas kebaikannya kepada kerajaan Majapahit yang dipimpin oleh Prabu Brawijaya.

b. Perbedaan pada kedua cerita tersebut terletak pada alur jika dalam Legenda Candi Pari menggunakan alur mundur, dapat dilihat dari cuplikan awal mula 
informan memulai cerita, "Candi pari itu dibangun sebagai tanda moksanya laki-laki yang bernama Jaka Pandelegan, kalau Candi Sumur itu istrinya yang bernama Nyai Roro Walang Angin karna dia berjasa ke Kerajaan Majapahit". Berbeda dengan Legenda Candi Sumur yang memiliki alur maju yang urut jalan ceritanya, dapat dilihat dari cuplikan awal mula informan bercerita, "Zaman Kerajaan Majapahit di masa Kerajaan Prabu Brawijaya dahulu di Desa Kedung Suko atau ras Di Desa Suko itu ada dua pasangan suami istri yang bernama Jaka Walang Tinunu dan istrinya bernama Nyai Roro Walang Sangit, Dan satunya lagi bernama Jaka Pandelegan dan istrinya bernama Nyai Roro Walang Angin".

c. Perbedaan selanjutnya adalah dalam segi latar yang mencakup 3 aspek, yakni latar waktu, latar tempat dan latar suasana. Perbedaan latar waktu, dalam kedua legenda sebenarnya tidak dijelaskan secara detail, namun hanya menjelaskan pada masa lampau di masa Kerajaan Majapahit perbedaannya adalah jika dalam legenda Candi Pari Kerajaan Majapahit dipimpin oleh Raja Hayam Wuruk, berbeda pula dalam Legenda Candi Sumur yang dipimpin oleh Prabu Brawijaya.

d. Perbedaan yang terakhir adalah dalam hubungan karya sastra terhadap kepercayaan, dalam Legenda Candi Pari adalah sebagai tempat ibadah/pemujaan dewa bagi masyarakat yang beragam Hindu, sedangkan Candi Sumur adalah tempat untuk mengambil air suci sebelum menuju ke tempat beribadah atau Candi Pari.

\section{Simpulan}

Struktur naratif legenda Candi Pari dan Candi Sumur saling memiliki keterkaitan term dan fungsi, berikut beberapa keterkaitan di antara kedua candi tersebut.

1. Adanya keterkaitan Unsur-unsur term yang terdapat dalam Legenda Candi Pari dan Sumur. Dalam Legenda Candi Pari terdapat 13 term yang terdiri atas $(\mathrm{a} 4+\mathrm{b} 5+\mathrm{c} 1)$ dan ada 6 tokoh dalam Legenda Candi Pari tersebut, sedangkan dalam Legenda Candi Sumur terdapat 12 terem yang terdiri atas $(a 5+b 3+c 1)$, 
dan ada 7 tokoh dalam Legenda Candi Sumur tersebut. Adapun selain dari tokoh yang ada dalam term sisanya adalah subjek yang berupa simbol.

2. Karakteristik yang paling menonjol antara dua candi itu adalah Candi Pari selalu identik dengan tempat ibadah/pemujaan bagi umat beragama Hindu, sedangkan candi sumur digunakan sebagai tempat untuk mengambil air guna menyucikan diri sebelum beribadah di Candi Pari.

3. Adanya keterkaitan unsur-unsur fungsi yang terdapat dalam legenda Candi Pari dan Candi Sumur. Dalam Legenda Candi Pari terdapat 18 fungsi yang terdiri atas (x6 + y5+ z4) dengan komposisi fungsi kebaikan lebih besar dibandingkan dengan keburukan. Sedangkan dalam Legenda Candi Sumur terdapat 17 fungsi yang terdiri atas $(x 6+y 6+z 2)$ dengan komposisi fungsi keburukan lebih besar daripada kebaikan.

4. Adanya keterkaitan unsur-unsur struktur naratif antara Legenda Candi Pari dan Candi Sumur. Legenda Candi Pari dan Candi Sumur memiliki persamaan dalam bidang tema yakni tema kepahlawanan, karena dari kedua legenda menjelaskan bahwa para raja/pemimpin akan membangunkan sebuah candi untuk mengenang jasa kedua suami istri tersebut yakni Jaka Pandelegen dan istrinya Nyai Roro Walang Angin. Kemudian, ada beberapa perbedaan pada kedua legenda tersebut yakni terletak pada alur, latar, dan hubungan karya sastra/legenda ini dengan kepercayaan masyarakat sekitar.

\section{Daftar Pustaka}

Astuti, A. M. (2016). Legendha Candhi Pari Lan Candhi Sumur Ing Desa Candipari Kecamatan Porong Kabupaten Sidoarjo. Baradha, 3(3), https://jurnalmahasiswa.unesa.ac.id/index.php/baradha/article/view/19328

Barthes, R. (2006). Mitologi. Yogyakarta: Kreasi Wacana.

Danandjaja, J. (2007). Foklor Indonesia. Jakarta: Pustaka Utama Grafiti.

Hutomo, S. S. (1991). Mutiara yang Terlupakan, Pengantar Studi Sastra Lisan. Surabaya: Komisariat HISKI Jawa Timur. 
Moleong, L. J. (2016). Metode Penelitian Kualitatif. Bandung: Remaja Rosda Karya.

Murniati. (2019). Keterampilan Menyimak Legenda dalam Pembelajaran Bahasa Indonesia. Skripsi, Fakultas Keguruan dan IImu Pendidikan, Universitas Sebelas Maret. https://doi.org/10.31227/osf.io/b8emd

Noermanzah, N. (2017). Plot in a Collection of Short Stories "Sakinah Bersamamu" works of Asma Nadia with Feminimism Analysis. Humanus: Jurnal IImiah IImu-ilmu Humaniora, 16(1), 33. https://doi.org/10.24036/jh.v16i1.7015

Putri, N. S., \& Nugraha, O. A. (2017). Perbandingan Struktur, Fungsi, dan Nilai Budaya pada Legenda Telaga Ngebel Ponorogo dan Legenda Danau Ranu Pasuruan. Jurnal Pena Indonesia, 3(2), 203. doi:10.26740/jpi.v3n2.p201-222

Sari, D. O. (2017). Anasir-Anasir Akulturasi Pada Candi Pari. Avatara e-Journal Pendidikan Sejarah, 5(2), 392-40, https://jurnalmahasiswa.unesa.ac.id/index.php/avatara/article/view/19249

Setyorini, N., \& Riskiana, S. (2018). Kajian Arkeptipal dan Nilai Kearifan Lokal Legenda di Kota Purworejo serta Relevansinya sebagai Bahan Ajar Mata Kuliah Kajian Prosa. Jurnal Pendidikan Bahasa dan Sastra, 17(2), 213. doi:10.17509/bs_jpbsp.v17i2.9659

Sudikan, S. Y. (2001). Metode Penelitian Sastra Lisan. Surabaya: Citra Wacana.

Wahyuningsih, I. (2016). Meninjau Kembali Tujuan Pendirian dan Fungsi Museummuseum di Kompleks Taman Wisata Candi Borobudur. Jurnal Konservasi Cagar Budaya, 10(2), 48. doi:10.33374/jurnalkonservasicagarbudaya.v10i2.155

Yulianto, A. (2016). Legenda Telaga Bidadari dan Legenda Jaka Tarub Sebuah Kajian Struktural Sastra Bandingan. UNDAS: Jurnal Hasil Penelitian Bahasa dan Sastra, 12(2), 79. doi:10.26499/und.v12i2.559 